\title{
Root-knot nematode Meloidogyne arenaria infecting Swiss Chard (Beta vulgaris subsp. cicla)
}

\author{
Faruk AKYAZI ${ }^{i}$ 1, Anıl Firat FELEK ${ }^{(D 2}$ \\ ${ }^{1}$ Ordu University, Agricultural Faculty, Plant Protection Department, Ordu, Turkey;
}

Alınış tarihi: 1 Kasım 2019, Kabul tarihi: 5 Haziran 2020

Sorumlu yazar: Faruk AKYAZI, e-posta: farukakyazi@hotmail.com

\begin{abstract}
Swiss Chard (Beta vulgaris subsp. cicla) is a vegetable crops growing in different regions of the world for variying purposes. Root-knot nematodes (Meloidogyne spp.) seem the potantial pest group on Swiss Chard according to the reported species from other countries. In this investigation, the root knot nematode (RKN) extracted from the root of Swiss Chard was identified as $M$. arenaria by using different primer sets (TRNAH-MRH106 and MORFMTHIS) targeting the large sub-unit ribosomal DNA (lrDNA) and the intergenic spacer (IGS) of rDNA of mitochondrial (mtDNA). Furthermore, the restriction enzymes (Hinfl and MnlI) for the fragments given by TRNAH-MRH106 primer set was also used for restriction and digestion. Finally, species-specific SCAR primers (Far/Rar) were performed to validation of the identification results. $M$. arenaria is considered as an important species among the major root knot nematodes in the world. In this context, the Swiss Chard as an intercroped, small-scale produced or randomly dispersed commodity must be observed as the potantial host for the nematode. This is especially important in case of any change for long term professional production planning in the same area for more valuable agricultural commodity.
\end{abstract}

Key words: Beta vulgaris subsp cicla, Root knot nematodes, Meloidogyne arenaria, Swiss chard
Pazı (Beta vulgaris subsp. cicla) bitkisi zararlısı kök-ur nematodu Meloidogyne arenaria

\section{Öz}

Pazı (Beta vulgaris subsp. cicla), çeşitli amaçlar için dünyanın farklı bölgelerinde yetişen bir sebze türüdür. Bazı ülkelerde kök-ur nematodları (Meloidogyne spp.) pazı üzerinde potansiyel zararlı grubu olarak bildirilmiştir. $\mathrm{Bu}$ araştırmada, Ordu ilinde pazı köklerinden elde edilen kök-ur nematodu (RKN)'nun, mtDNA'nın bölgelerini (lrDNA ve IGS) hedefleyen farklı primer setleri (TRNAH-MRH106 ve MORF-MTHIS) kullanılarak teşhisi yapılmış ve $M$. arenaria olarak tanımlanmıştır. Ayrıca, TRNAHMRH106 primer setinin kullanımı ile elde edilen DNA bant büyüklüklerini kesme işlemi için Hinfl ve MnlI enzimleri de kullanılmıştır. Son olarak, teşhis sonuçları türe özgü SCAR primerleri (Far/Rar) kullanılarak doğrulanmıştır. M. arenaria, dünyadaki başlıca kök-ur nematodları arasında önemli bir tür olarak kabul edilmektedir. Bu bağlamda kök-ur nematodları, küçük ölçekli üretilmiş veya rastgele dağılmış bir ürün olarak pazının potansiyel konukçusu olarak gözlenmesi gerekir. $\mathrm{Bu}$ durum özellikle, aynı alanda daha değerli tarımsal ürünlerin uzun vadeli profesyonel üretim planlaması durumunda herhangi bir değişiklik olması durumunda önemlidir.

Anahtar kelimeler: Beta vulgaris subsp cicla, kökur nematodları, Meloidogyne arenaria, pazı 


\section{Introduction}

Swiss chard (Beta vulgaris cicla, BVc) is member a of the Chenopodiaceae (Ninfali and Angelino, 2013). Beta vulgaris subsp. vulgaris var. cicla is called by different names in worlwide as Chard, Swiss chard, beet greens, spinach beet (EPPO, 2020) and known the leaf beet group vegatable crop (Lange et al. 1999, McGratht, 2011,). The total cultivated area is not known exactly in worlwide, but it is consumed for its leaves in salads or in case of more ripening also cooked in the recipies as spinach done. In addition, the chard is used as pot and medicinal herb (Biancardi et. al., 2011). BVc became commercially important in 19th century in Europe (Norton and Esposito, 1994). The crop is also popular in Turkey. The planted area was 6.278 da and the production was 9.631 tons in total for 2018 (TUIK, 2019). Even it is commercially available in the markets, especially produced in the gardens for small scale consumption by families. Ordu is one of the province revealing traditional vegetable production aspects such as home garden practices for local family consumption and also small scale production by traditional methods for markets. The chard is mainly the intercrop among other vegetables in small gardens, but also planted 37 da area and produced 45 tons in 2018 in Ordu, Turkey (TÜIK, 2019).

Chard production was affected by different pest and disease agents and one of them as an important group is the genus Meloidogyne. The genus is capable to infect more than 5,500 plant species (Trudgill and Blok, 2001) and some species of the genus were also reported on chard. Meloidogyne spp. in Cyprus (Philis, 1983), M. hapla in Germany (Decker, 1989), M. incognita var. acrita in Africa (Martin, 1959), M. arenaria in Spain (Millán de Aguirre, 1991), M. enterelobii in Mexico (Bastidas et. al., 2019), Meloidogyne spp. in Iraq and Turkey (Kareem et. al., 2017) were the countries and root knot nematode species reported with Chard. In Turkey, some studies on identification and distribution of root-knot nematodes have been conducted on different vegetables by different research groups (Elekçioğlu et al., 1994; Mennan and Ecevit 1996; Kaşkavalcı and Öncüer 1999; Söğüt and Elekçioğlu, 2000; Özarslandan and Elekçioğlu, 2010; Çetintaş and Çakmak, 2016; Uysal et. al., 2017), but M. arenaria species have not been reported on swiss chard. As determined in previous investigations, Meloidogyne species are in relation with chard and must be identified in case of the likelihood of encounter with a new Meloidogyne species on the crop. In this context, we found the crop infested in a small garden-field and identified the species in order to confirm the previous studies and also contribute to the crop in a different region as the host status for Meloidogyne species.

\section{Material and Methods}

\section{Nematode sampling and extraction}

The plant was encountered by chance during a visit in a small garden in 2018. When the infected chard roots were observed (Figure 1), the root samples were transferred into a polyethylene bag and then carried to the laboratory and stored at $4^{\circ} \mathrm{C}$ in refrigerator till the nematode extraction process. For the extraction, the infected swiss chard roots were dissected under a stereomicroscope (Leica, S8APO) at $10 \mathrm{x}$ magnification. Females were collected separately and used for molecular characterization.

\section{DNA extraction and PCR amplification}

For DNA extraction, a single mature female was transferred into $10 \mu \mathrm{l}$ of extraction buffer $(1 \mathrm{mM}$ EDTA, $10 \mathrm{mM}$ Tris, $0.1 \mathrm{mg} / \mathrm{ml}$ proteinase $\mathrm{K}$ and 0.1 $\%$ triton $\mathrm{X}$ ) in a $1.5 \mathrm{ml}$ tube, and the females were disrupted using a probe (Pagan et al., 2015). Samples were frozen at $-20^{\circ} \mathrm{C}$ overnight in $0.2 \mathrm{ml}$ PCR tubes. Then, samples were incubated at $56^{\circ} \mathrm{C}$ for $1 \mathrm{~h}$ followed by $95^{\circ} \mathrm{C}$ for $10 \mathrm{~min}$, and used immediately for PCR or stored at $-20^{\circ} \mathrm{C}$.

The primer sets TRNAH and MRH106 or MORF/MTHIS developed by Stanton et al. 1997 were used to amplify the mitochondrial DNA fragments. The primer sequences are given in Table 1 . Total reaction volume was $25 \mu \mathrm{l}$ containing DreamTaq Green PCR Master Mix (2X) (Thermo Fisher Scientific), $1.5 \mu \mathrm{l}$ of DNA, and $0.5 \mu \mathrm{M}$ of each primer. The thermal cycling was performed in the Veriti Thermal Cycler. The thermo cycling reactions using the primers TRNAH/MRH106 and MORF/MTHIS (Stanton et al., 1997; Pagan et al., 2015) were as follows: $95^{\circ} \mathrm{C}$ for $3 \mathrm{~min}$, followed by 40 cycles of $95^{\circ} \mathrm{C}$ for $30 \mathrm{sec}$., $50^{\circ} \mathrm{C}$ for $30 \mathrm{sec} .68^{\circ} \mathrm{C}$ for $1 \mathrm{~min}$, and a final extension step of $68^{\circ} \mathrm{C}$ for $7 \mathrm{~min}$. DNA fragments were separated by electrophoresis in $1 \mathrm{x}$ TAE (Tris-acetic acid- EDTA buffer) using 1\% agarose gels containing Etidium Bromid for $25 \mathrm{~min}$ at $150 \mathrm{~V}$ and visualized under UV light using GENBOX imagER. Secondly, in order to determine the mitochondrial haplotype, the fragments amplified using the primer set, TRNAH and MRH106 were subjected to restriction digestion according to the 
restriction enzymes Hinfl and MnlI (New England Biolabs, Ipswich, MA) as recommended by the manufacturer. Finally, the identity of the sample was also confirmed by species specific SCAR primer set Far/Rar developed for M. arenaria (Zijlstra et al.,
2000). The PCR conditions $95^{\circ} \mathrm{C}$ for $3 \mathrm{~min}$, followed by 40 cycles of $95^{\circ} \mathrm{C}$ for $30 \mathrm{sec}^{\circ}, 61^{\circ} \mathrm{C}$ for $30 \mathrm{sec} .68^{\circ} \mathrm{C}$ for $1 \mathrm{~min}$, and a final extension step of $68^{\circ} \mathrm{C}$ for 7 $\min$.

Table 1. Primer sets used for identification of root-knot nematode Meloidogyne arenaria.

\begin{tabular}{ccc}
\hline Primer & Primer sequences & Reference \\
\hline TRNAH & 5' TGAATTTTTTATTGTGATTAA 3' & Stanton et al. 1997 \\
MRH106 & 5' AATTTCTAAAGACTTTTCTTAGT 3' & Stanton et al. 1997 \\
MORF & 5' ATCGGGGTTTAATAATGGG 3' & Stanton et al. 1997 \\
MTHIS & 5' AAATTCAATTGAA ATTAATAGC 3' & Stanton et al. 1997 \\
Far & 5' TCGGCGATAGAGGTAAATGAC 3' & Zijlstra et al., 2000 \\
Rar & 5' TCGGCGATAGACACTACAACT 3' & Zijlstra et al., 2000 \\
\hline
\end{tabular}

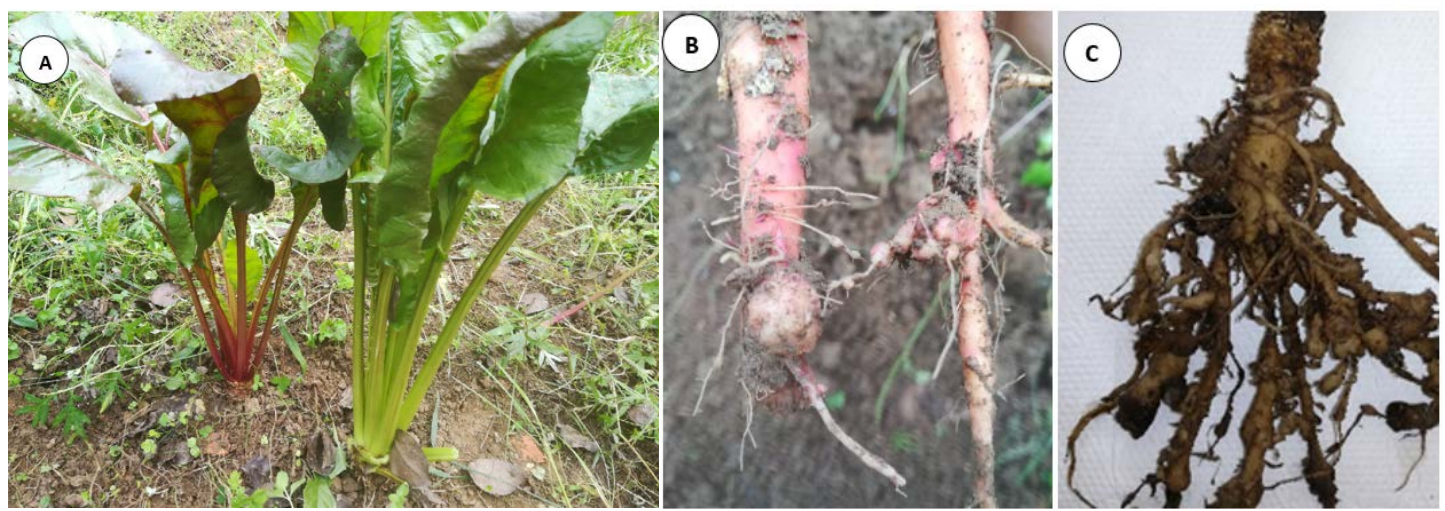

Figure 1. Appearance of swiss chard plant in the field (A) and roots with root-knot nematode gall symptoms (B,C) caused by Meloidogyne arenaria.
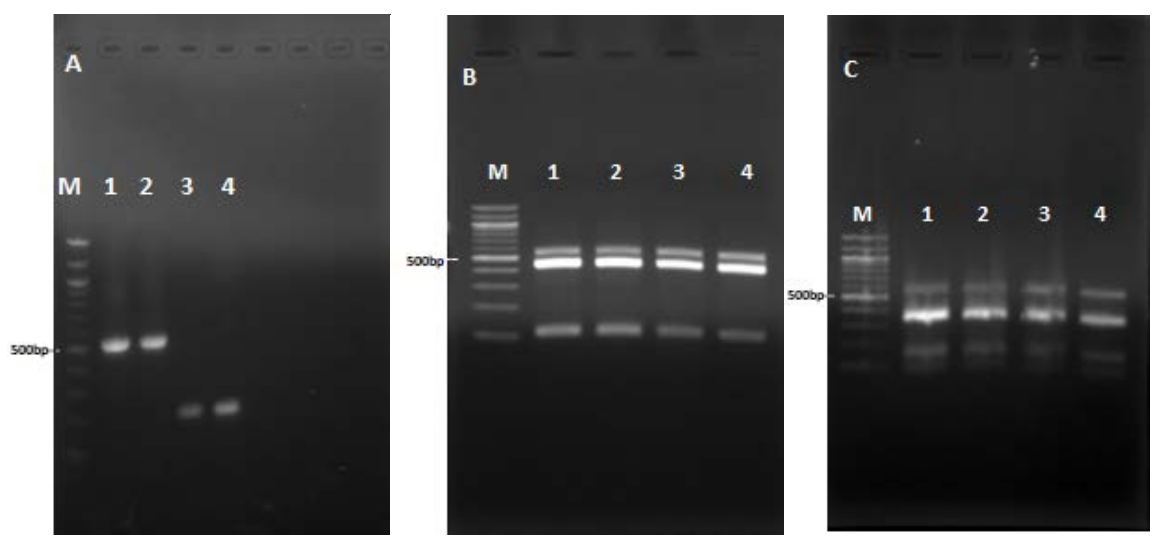

Figure 2. $557 \mathrm{bp}$ fragments of TRNAH/MRH106 primers (Line;1,2) and $214 \mathrm{bp}$ fragments of MORF/MTHIS primers (Line;3,4) for M.arenaria. (A). The digestion assay of TRNAH/MRH106 using Hinfl showed 445 and 112 bp products (B) and MnlI gave three digestion products of 340, 140 and 77 bp in M. arenaria (C). Lanes labeled M contain $100 \mathrm{bp}$ marker ladder (Fermentas), with the position of the $500 \mathrm{bp}$ band indicated by an arrow. 


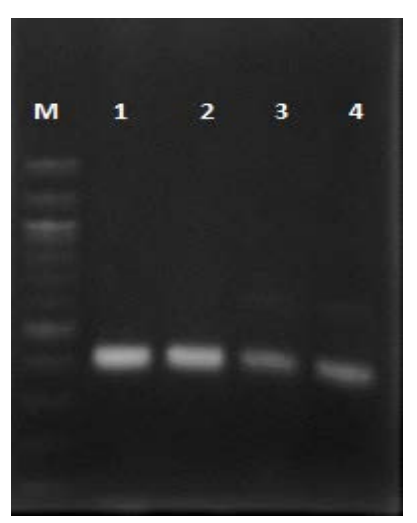

Figure 3. Amplification products of Meloidogyne arenaria with specific SCAR primer set Far/Rar (Line;1,2,3,4= 420 bp fragment; M: $100 \mathrm{bp}$ marker ladder).

\section{Results}

Root-knot nematode $M$. arenaria was detected on swiss chard plant. A PCR was conducted using primer set TRNAH/MRH106 and PCR amplification of the primers revealed fragments of 557 bp for $M$. arenaria (Figure 2A; Line 1,2). For the primers MORF and MTHIS, a fragment was obtained in size of 214 bp (Figure 2A; Line 3, 4). The PCR product of TRNAH/MRH106 primers was processed for the digestion assay using Hinfl enzyme and this showed 445 and 112 bp products for M. arenaria (Figure 2B). The digestion assay of the enzyme $M n l I$ gave three digestion products of 340,140 and 77 bp for $M$. arenaria (Figure 2C).

These results were also confirmed by using speciesspecific SCAR primer set Far/Rar showed 420 bp fragment for $M$. arenaria (Figure 3). This study results showed agreement with earlier studies Adam et al., (2007) and Zijlstra et al., (2000).

\section{Conclusion}

The production of the Swiss Chard is in small scale for Turkey and the production system is mainly based on family size production and traditional methods. It is easy to observe the intercrop status of this crop in Black Sea region and espacially in Ordu province. The production was also accompanied with the randomly dispersed production model of the crop in the fields or gardens and the lack of the modern approach results in non-management of pest or disease problems of the crop. This is also valid for root not nematodes. In this context, consideration of the crop as the host of $M$. arenaria is important, because yield losses are effected by the low population of nematodes in the soil. Swiss Chard may contribute this by increasing numbers of $M$. arenaria in the soil for the region. Especially, the nematode species is the one mentioned among the most encountered four species in worldwide (Taylor et. al. 1982) and identified different regions of Turkey as well (Devran and Söğüt, 2009, Akyazı et. al. 2012, Aydınlı ve Mennan, 2016). The previous researches are also the reported that major important root-knot nematodes prefer Swiss Chard as an host (Martin, 1959, Philis, 1983, Decker, 1989, Millán de Aguirre, 1991).

In conclusion, Swiss Chard is a potantial crop to spread and support the presence status of $M$. arenaria in the region and this is especially important in case of any change for long term professional production planing in the same area for more valuable agricultural commodity.

\section{References}

Adam, M. A. M., Phillips, M. S., \& Blok, V.C. (2007). Molecular diagnostic key for identification of single juveniles of seven common and economically important species of root-knot nematode (Meloidogyne spp.). Plant Pathology, 56, 190-197.

Akyazı, F., Han, H., Çetintaș, R., \&Felek, A. F. (2012). First report of root-knot nematodes, Meloidogyne arenaria and M. hapla (Nemata: Meloidogynidae) from pepino in Turkey. Nematologia Mediterranea, 40(2), 107-110.

Aydınlı, G., \& Mennan, S. (2016). Identification of rootknot nematodes (Meloidogyne spp.) from greenhouses in the Middle Black Sea Region of Turkey. Turkish Journal of Zoology, 40, 675-685.

Bastidas, M. R., Curiel M.G. M., Fasio A. C., Contreras M. R., Rubio J. S. H. \& Osuna J.de D.D. (2019). Identification and distribution of Meloidogyne species in Baja California Sur, Mexico. Revista Mexicana de Ciencias Agrícolas. 10(2), 337-349. 
Biancardi, E., Panella, L. W. \& Lewellen, R. T. (2011). Beta maritima, the origin of beets. Springer Science \& Business Media.294 p.

Çetintaş, R. \& Çakmak, B. (2016). Meloidogyne species infesting tomatoes, cucumbers and eggplants grown in Kahramanmaraş Province, Turkey. Turkish Journal of Entomology, 40(4), 355-364.

Decker, H. (1989). Plant Nematodes and Their Control, Phytonematology ( Ed. N.M. Sveshnicova). E. J. Brill (Usa). Printed in India at Pauls Press, New Delhi. Sf 262 den .540 pp.

Devran, Z., \& Söğüt, M. A. (2009). Distribution and identification of root-knot nematodes from Turkey. Journal of Nematology, 41(2), 128-133.

Eppo, 2019. European and Mediterranean Plant Protetion Organization. https,//www.eppo.int/ (15.11.2019).

Kareem, K. H., Ahmed, N. H., Gürkan, T., Akbay, N. G., Salai, S. A. F., \& Çetintaş, R. (2017). Diagnosis of Nematode Populations Found in Chard, Barley and Onion Grown in North of Iraq and South of Turkey. Kahramanmaraş Sütçü İmam Üniversitesi Doğa Bilimleri Dergisi, 20(1), 28-34.

Kaşkavalcı, G., \& Öncüer, C. (1999). Investigations on distribution and economic importance of Meloidogyne goeldi, 1887 (Tylenchida, Meloidogynidae) species found in the major areas of hot climate vegetables in Aydın province. Turkish Journal of Entomology, 23(2), 149-160.

Lange, W, Brandenburg W. A., \& De Bock TSM (1999). Taxonomy and cultonomy of beet (Beta vulgaris L.). Bot J Linn Soc.130, 81-96

Martin, G. C. (1959). Plant species attacked by root-knot nematodes (Meloidogyne spp.) in the Federation of Rhodesia and Nyasaland. Nematologica, 4(2), 122125.

McGrath, J. M., Panella, L., \& Frese, L. (2011). Beta (p,1-29) In, Kole, C. (2011). Wild Crop relatives, genomic and breeding resources, Industrial crops. Springer.

Millán de Aguirre, J. R. (1991). Especies del género Meloidogyne presentes en los cultivos de la C. A. Vasca. Estudios de Fitopatología. S E F. Consejería de Agricultura, Badajoz, Spain, 164-167.
Ninfali, P., \& Angelino, D. (2013). Nutritional and functional potential of Beta vulgaris cicla and rubra. Fitoterapia, 89, 188-199.

Norton, P. B., \& Esposito, J.J. (1994). The New Encyclopaedia Britannica Encyclopedia Britannica Inc., Chicago

Pagan, C., Coyne, D., Carneiro, R., Kariuki, G., Luambano, N., Affokpon, A., \& Williamson. V. M. (2015). Mitochondrial haplotype-based identification of ethanol-preserved root-knot nematodes from Africa. Phytopathology, 105(3), 350-357.

Philis, J. (1983). Occurrence of Meloidogyne spp. and races on the island of Cyprus. Nematologia Mediterranea, 11, 13-19.

Özarslandan, A., \& Elekçioğlu, İ. H. (2010). Identification of the Root-knot nematode species (Meloidogyne spp.) (Nemata, Meloidogynidae) collected from different parts of Turkey by molecular and morphological methods. Turkish Journal of Entomology, 34(3), 323-335.

Söğüt, M.A., \& Elekçioğlu, İ.H. (2000). Determination of Meloidogyne goeldi, 1892 (Nemata, Heteroderidae) species races found in vegetable growing areas of the Mediterranean region of Turkey. Turkish Journal of Entomology, 24(1), 33-40.

Stanton, J., Hugall, A., \& Moritz, C. (1997). Nucleotide polymorphisms and an improved PCR-based mtDNA diagnostic for parthenogenetic rootknot nematodes (Meloidogyne spp.). Fundamental Applied Nematology, 20(3), 261-268.

Taylor, A. L., Sasser, J. N. \& Nelson, L. A. (1982). Relationship of climate and soil characteristics to geographical distribution of Meloidogyne Species in agricultural soils. IMP, contract No. AID/ta-c-1234, Raleigh, North Carolina, U.S.A.

Trudgill, D. L., \& Blok, V. C. (2001). Apomictic Polyphagous Root Knot Nematodes, Exceptionally Successful and Damaging Biotrophic Root Pathogens. Annual Review Phytopathology, 39(1), 53-77.

TUIK. (2019). Türkiye İstatistik Kurumu. http,//www.tuik.gov.tr/UstMenu.do?metod=istgos terge (10.10.2019). 
Uysal, G., Söğüt, M. A., \& Elekçioğlu, İ. H. (2017). Identification and distribution of root-knot nematode species (Meloidogyne spp.) in vegetable growing areas of Lakes Region in Turkey. Turkish Journal of Entomology, 41(1),105-122.
Zijlstra, C., Donkers-venne, D. T. H. M., \& Fargette, M. (2000). Identification of Meloidogyne incognita, $M$. javanica and $M$. arenaria using sequence characterised amplified region (SCAR) based PCR assays. Nematology, 2(8), 847-853. 